\title{
Carbon dioxide sequestration in terrestrial ecosystems
}

\author{
Joe Wisniewski ${ }^{1}$, Robert K. Dixon ${ }^{2}$, John D. Kinsman ${ }^{3}$, R. Neil Sampson ${ }^{4}$, Ariel E. Lugo \\ ${ }^{1}$ Wisniewski \& Associates, Inc., 6862 McLean Province Circle, Falls Church, Virginia 22043, USA \\ ${ }^{2}$ Environmental Research Laboratory, U.S. Environmental Protection Agency, 200 SW 35th St., Corvallis, Oregon 97333, USA \\ ${ }^{3}$ Edison Electric Institute, Environmental Affairs Division, 701 Pennsylvania Ave., NW, Washington, DC 20004-2696, USA \\ ${ }^{4}$ American Forests, 1516 P St., NW, Washington, DC 20005, USA \\ ${ }^{5}$ USDA Forest Service, Call Box 25000, Rio Piedras, Puerto Rico 00928-2500, USA
}

\begin{abstract}
The terrestrial biosphere plays a prominent role in the global carbon (C) cycle. Although a net source of $C$, some terrestrial ecosystems are currently accumulating $C$ and it appears feasible to manage existing terrestrial (forest, agronomic, desert) ecosystems to maintain or increase $C$ storage. Forest ecosystems can be managed to sequester and store globally significant amounts of $\mathrm{C}$. Agroecosystems and arid lands could be managed to conserve existing terrestrial $\mathrm{C}$ but $\mathrm{CO}_{2}$ sequestration rates by vegetation in these systems is relatively low. Biomass from forest agroecosystems has the potential to be used as an energy source and trees could be used to conserve energy in urban environments. Some ecosystem management practices that result in $\mathrm{C}$ sequestration and conservation provide ancillary benefits.
\end{abstract}

\section{INTRODUCTION}

Anthropogenic activities, including combustion of fossil fuels and land-use change, contribute carbon dioxide $\left(\mathrm{CO}_{2}\right)$ emissions to the global carbon (C) cycle. Current annual $\mathrm{CO}_{2}$ emissions are estimated at $7.5 \pm 1.5$ petagrams $\left(\mathrm{Pg}=\mathrm{g} \times 10^{15}\right)$ as $\mathrm{C}$ (Sundquist 1993). The atmospheric $\mathrm{CO}_{2}$ reservoir is increasing by $3.4 \pm 0.2 \mathrm{Pg}$ annually (Tans et al. 1990). Atmospheric $\mathrm{CO}_{2}$ concentrations are approximately $360 \mathrm{ppm}$. The world's oceans are believed to be a net sink of $2.0 \pm 0.8$ $\mathrm{Pg} \mathrm{C}$ annually, leaving the terrestrial biosphere as a sink up to $4 \mathrm{Pg} \mathrm{C}$ annually (Tans et al. 1990, Sundquist 1993). Terrestrial ecosystems of the northern hemisphere have been identified as a potential C sink (Tans et al. 1990, Kauppi et al. 1992, Sedjo 1992), although some tropical forests are also accumulating significant amounts of $C$ (Brown et al. 1992). The precise role of the terrestrial biosphere in the global $\mathrm{C}$ cycle remains uncertain.

Carbon dioxide is among the most important anthropogenic greenhouse gases (Houghton et al. 1990, Sundquist 1993). Potential actions to mitigate fossil fuel emissions include increased energy conservation and efficiency, employment of renewable energy systems and use of alternative fuels (NAS 1991). Other greenhouse gas mitigation options include sequestration of $\mathrm{CO}_{2}$ in biologic 'sinks' such as plant biomass. For example, $\mathrm{C}$ can be sequestered in trees and durable forest products, in agronomic crops, in halophytes (salt-tolerant plants), as organic matter in soil, and in marine plants such as microalgae for decades or centuries. Alternatively, biomass from terrestrial systems can be used as an energy source and offset fossil fuel $\mathrm{CO}_{2}$ emissions.

Given the scientific uncertainty regarding global climate change and $\mathrm{C}$ cycling the purpose of this report is to: (1) review current information describing the role of the terrestrial biosphere in the global $\mathrm{C}$ cycle, and (2) consider the potential role of sequestering or conserving $\mathrm{C}$ in forest and agroecosystems to mitigate the accumulation of greenhouse gases in the atmosphere.

\section{FORESTS}

Globally, boreal, temperate and tropical forest systems contain approximately $1200 \mathrm{Pg} \mathrm{C}$ and cycle 70 to $90 \mathrm{Pg}$ C annually (Kauppi et al. 1992, Sedjo 1992). 
Forest ecosystems can be net sources or sinks of $\mathrm{CO}_{2}$, depending on dominant biological or physical factors, including: (1) state of the soil and vegetation (i.e. is the system undisturbed, disturbed or recovering?); (2) management practices at the site level; (3) environmental conditions (e.g. climatic, edaphic, fire, pests); and (4) atmospheric deposition of pollutants and other compounds, some of which (e.g. $\mathrm{CO}_{2}$ and nitrogen) can serve as nutrients [Kauppi et al. 1992, Cropper \& Gholz 1993 (this volume, p. 7-12)].

Forests within tropical latitudes are being harvested for timber export, fuelwood, shifting cultivation, permanent agriculture, pasture, and urbanization [(Detwiler \& Hall 1988, Iverson et al. 1993 (this volume, p. 23-38)]. The most recent estimate of annual tropical deforestation is approximately 17 million ha (Houghton et al. 1990). Land-use change in forest ecosystems of tropical latitudes is a major $\mathrm{CO}_{2}$ source, but the range of emissions estimates is around $1.6 \pm 1.0 \mathrm{Pg} \mathrm{C}$ annually (Sundquist 1993).

Although land-use change influences forest $C$ emissions, many forest regions which previously were believed to be in $\mathrm{C}$ equilibrium actually may be net $\mathrm{C}$ sinks (Tans et al. 1990, Kauppi et al. 1992). For example, mature tropical forests in southeast Asia have been shown to be accumulating $C$ (Iverson et al. 1993). In addition, high $\mathrm{C}$ storage rates have been observed in tropical forests recovering from logging (Brown et al. 1992). Temperate and boreal forest biomass has been expanding substantially in Europe, North America and possibly the former Soviet Union [Sedjo 1992, Kolchugina \& Vinson 1993 (this volume, p. 13-21)]. Inventories of western Europe reveal forest area and growing stock increased 30 and $25 \%$, respectively, over the period 1971 to 1990 (Kauppi et al. 1992).

At the individual plant level, photosynthesis is dependent on ambient $\mathrm{CO}_{2}$ concentration, light, temperature and other factors (Mooney et al. 1991, Cropper \& Gholz 1993). Strain \& Thomas (1992) reviewed the literature on plant response to elevated $\mathrm{CO}_{2}$ and concluded: (1) if other resources are present at required levels, $\mathrm{CO}_{2}$ enrichment will increase photosynthesis and plant growth; (2) plants limited by resource deficiencies (e.g. nitrogen or phosphorus) will respond slightly or not at all to $\mathrm{CO}_{2}$ enrichment; (3) $\mathrm{CO}_{2}$ reduces transpiration and improves plant water status, due to increasing photosynthesis and decreased water loss; and (4) $\mathrm{CO}_{2}$ and global warming may affect species differentially and will result in ecosystem flora and fauna change. The potential of individual trees to act as a $C$ sink may be highly dependent on response to soil nutrition and environmental stress rather than to atmospheric $\mathrm{CO}_{2}$ concentration (Norby et al. 1992). Forest ecosystem $\mathrm{C}$ balances appear to be sensitive to annual differences in climate and possibly $\mathrm{CO}_{2}$ enrich- ment (Mooney et al. 1991, Cropper \& Gholz 1993). In addition, climate change may result in an increased rate of decomposition and plant respiration, thus releasing additional $\mathrm{CO}_{2}$ to the atmosphere.

Three broad classes of forest management actions could influence $C$ conservation and sequestration in forest ecosystems: (1) decreasing deforestation and forest degradation; (2) establishing additional areas of forest; and (3) implementation of practices which stimulate $\mathrm{CO}_{2}$ fixation by existing forest or agroforest systems (Winjum et al. 1992). Trade-offs may exist between high rates of $\mathrm{C}$ assimilation and large amounts of $\mathrm{C}$ storage. Young trees have high growth rates but contain relatively little $\mathrm{C}$, while the opposite is true of some mature trees (Cooper 1983). Consequently, if biomass is harvested to maintain high growth rates, the accumulated $\mathrm{C}$ must be stored to prevent its return to the atmosphere as $\mathrm{CO}_{2}$. Harvested wood could be used as durable wood products or could be placed in longterm storage (Kolchugina \& Vinson 1993).

Carbon conservation in tree biomass can be achieved by reducing the rate of tropical deforestation. Trees harvested and burned or left to decay within tropical Iatitudes release 1 to $4 \mathrm{Pg} \mathrm{C}$ to the atmosphere annually (Iverson et al. 1993). Many types of replacement ecosystems (e.g. agriculture and pasture) do not fix atmospheric $\mathrm{CO}_{2}$ in significant amounts relative to undisturbed forest. Brown et al. (1992) and Iverson et al. (1993) analyzed the potential $C$ that could be sequestered in mature, logged and plantation forests in tropical latitudes based on climate, soil and topography. Iverson et al. (1993) and Trexler \& Meganck (1993, this volume, p. 129-136) assert tropical forest plantations are significant potential sinks of $\mathrm{C}$.

Carbon sinks can be increased by planting additional areas of new trees or by increasing the growth rate of existing forest ecosystems. Management practices to foster $\mathrm{C}$ sequestration include: afforestation, reforestation and establishment of agroforestry systems [(Dixon et al. 1993b, c, Trexler \& Haugen 1993, Winjum \& Lewis 1993 (this volume, p. 111-119)]. Carbon storage following forest and agroforest system establishment ranges from 10 to 40,20 to 150 and 30 to $200 \mathrm{Mg} \mathrm{C}$ for boreal, temperate and tropical forest ecosystems, respectively (Dixon et al. 1993b, c). Grainger (1988) estimated that up to 1 billion ha of technically suitable land is available for forestation or establishment of agroforest ecosystems. Silvicultural practices might be implemented to improve existing forest growth rates and $\mathrm{C}$ accumulation including: optimizing stem density, pruning, weed control, fire and pest control, fertilization, irrigation, and site preparation (Wall 1992).

Agroforestry, the dual cultivation of forest and agricultural crops to achieve optimal production of both, 
is a land-use practice which may lead to enhanced C sequestration (Schroeder 1993, this volume, p. 53-60). Establishment of sustainable agroforest systems could offset shifting cultivation and deforestation within tropical latitudes [Sanchez \& Bennites 1987, Unruh et al. 1993 (this volume, p. 39-52)]. Trexler \& Haugen (1993) reported up to 160 million ha are available for establishment of agroforestry systems worldwide.

Several assessments have suggested management of forest systems could increase $C$ storage in the terrestrial biosphere and thus slow accumulation of greenhouse gases in the atmosphere (Lugo \& Wisniewski 1992, Dixon et al. 1993b, c). Globally, an intensive program of reforestation, afforestation, and establishment of agroforest systems could conserve and/or sequester $55 \mathrm{Pg}$ of C over $50 \mathrm{yr}$ (Winjum et al. 1992, Dixon et al. 1993c), a significant fraction of the current annual atmospheric increase of $3.5 \mathrm{Pg} \mathrm{C}$. However, these analyses have not fully considered future potential global climate change in their estimates [Cramer \& Solomon 1993 (this volume, p. 97-110), King 1993 (this volume, p. 61-78)].

\section{SOILS, AGROECOSYSTEMS AND ARID LANDS}

Globally, soil systems contain up to $3 \times$ more $C$ than above-ground biomass (Schlessinger 1990, Dixon \& Turner 1991). About $470 \mathrm{Pg}$ of terrestrial C is contained in boreal, temperate and tropical forest soils (Dixon et al. 1993b). Another 270 Pg C occurs in savanna and cultivated soils. Management practices can lead to rapid changes in soil $\mathrm{C}$ and influence $\mathrm{CO}_{2}$ cycling with the atmosphere (Schlessinger 1990, Johnson 1992). Some ecosystem management practices (e.g. cultivation and prescribed fires) lead to soil C loss, while agronomic crop fertilization, reduced tillage, and lowintensity prescribed burning can increase $\mathrm{C}$ storage (Johnson 1992). In general, increased C accumulation is associated with practices that promote cooler soils (e.g. mulch, shade), wetter soils (irrigation), fertile soils (amendments) and soils with reduced aeration (limit tillage). Carbon accretion rates for selected land management practices range from $21 \mathrm{Mg} \mathrm{C}$ annually for stubble-mulch wheat fallow systems in semi-arid regions to $240 \mathrm{Mg} \mathrm{C}$ annually from heavy manuring in the tropical soils (Dixon et al. 1993c). Leemans \& Solomon (1993, this volume, p. 79-96) evaluated the potential response and redistribution of agronomic crops under future climate change scenarios and determined that high latitude systems will benefit from global warming due to longer growing periods and increased productivity.

Approximately one-half of the earth's land surface is arid or semi-arid with one-third of the deserts resulting from human activity (Grainger 1988). Some arid ecosystems can be successfully rehabilitated and cultivated with halophytes (salt-tolerant plants). About $1.3 \times 10^{6} \mathrm{~km}^{2}$ of the world's $7 \times 10^{6} \mathrm{~km}^{2}$ of salt desert habitat could be revegetated with halophytes. Total $\mathrm{C}$ sequestration by desert halophytes is potentially comparable to that of temperate forest plantations (Glenn et al. 1992a, b). As biomass crops, halophytes have the global potential to directly sequester up to $0.7 \mathrm{Pg} \mathrm{C}$ annually. The key advantage of using halophytes is that they can grow in saline soils that are less useful for conventional agriculture and can be irrigated with salt or sea water.

\section{BIOENERGY SYSTEMS}

Utilization of biomass as a substitute for fossil fuels is one method to minimize greenhouse gas emissions (NAS 1991). Production of energy from biomass is a growing practice in the United States, where cogeneration plants associated with wood processing facilities have helped reduce energy costs while reducing air and water pollution (Graham et al. 1992). Co-generation with biomass results in $\mathrm{C}$ recycling, using solar energy, rather than extracting and oxidizing fossil carbon from the earth. Carbon dioxide released during biomass combustion can be sequestered by replacement trees.

Production of electricity using short-rotation woody crops is estimated to have the potential, with advances in energy conversion and crop yield, to reduce U.S. fossil fuel $\mathrm{CO}_{2}$ emissions by $20 \%$ (Graham et al. 1992). Combustion of wood in coal-fired boilers also is possible, and a promising long-term prospect is technologically advanced gas turbines fired by gasified biomass from various feedstocks (RTI 1991). There is a large energy penalty for converting wood to liquid fuels and the net efficiency of petroleum replacement is very low (Marland \& Marland 1992). However, the opportunity may exist to nearly double the energy produced per hectare of woody crops due to both yield increases and improved conversion efficiency (Graham et al. 1992). At present, the use of tree biomass as fuel by utilities is economical only for small power plants near the biomass source.

Trees also can be used to help conserve energy in urban areas. Strategic planting of shade trees in cities with substantial air conditioning requirements can reduce energy use and fossil fuel $\mathrm{CO}_{2}$ emissions. Similarly, trees may also serve as wind breaks and reduce winter heating needs by 4 to $22 \%$ (DeWalle 1978). Akbari et al. (1988) assert that urban trees are $15 \times$ more important in reducing $\mathrm{CO}_{2}$ build-up than rural trees. It has been estimated that improving the 
existing urban forests in the United States could result in lowering total $\mathrm{C}$ emissions by 1 to $3 \%$ (Sampson et al. 1992). A detailed guidebook has been published on strategic landscaping with trees to increase energy conservation and efficiency (U.S. EPA 1992).

\section{SUMMARY}

Several opportunities to sequester and conserve terrestrial $C$ have been identified in this report: (1) decreasing deforestation and maintaining existing C pools; (2) establishing additional areas of forest to foster $C$ sequestration; (3) increasing the productivity of existing forests and $C$ sequestration; (4) employing agroforestry as a land-use practice to conserve and sequester $C_{i}$ (5) managing soil systems, agronomic and desert crops as $C$ sinks; and (6) offsetting fossil fuel combustion with biomass or biomass-derived fuels. Additional opportunities may exist to sequester $C$ in oceans and other terrestrial ecosystems. Further analysis is required to establish realistic limits on the potential impact of these management practices on atmospheric $\mathrm{CO}_{2}$

Sequestration and conservation of $\mathrm{C}$ in forest and agroecoystems can be achieved at relatively low initial cost (NAS 1991, Dixon et al. 1993a). The implementation of such practices can lead to a positive rate of financial return. In a 1991 assessment of forest establishment practices and their costs at the site level for 94 forested nations of the world, the marginal cost of sequestering 55 to $70 \mathrm{Pg} \mathrm{C}$ was approximately US $\$ 10$ per Mg C (Dixon et al. 1993b). Within the boreal forests of Russia, forestation can sequester C for US $\$ 1$ to 3 per Mg C (Krankina \& Dixon 1993). These analyses did not consider the stream of benefits which flow from forest systems such as food, fuel, fiber, protection of watersheds and soils, and other environmental benefits. Forests are established and managed within a positive financial rate of return in many regions of the world (Gregerson et al. 1989).

In a recent review of the role of the terrestrial biosphere in the global $C$ cycle several conclusions were promulgated in an international forum: (1) rising $\mathrm{CO}_{2}$ accelerates net primary productivity and probably increases C storage in terrestrial ecosystems; (2) a vast number of managed and natural terrestrial ecosystems are increasing their $\mathrm{C}$ storage and the quantity may be large enough to account for the so-called 'missing $C$ '; and (3) appropriate ecosystem management can enhance net $C$ storage and is a compatible goal with conservation of biodiversity, sustainable land use, energy conservation and economic development (Lugo \& Wisniewski 1992).
With the advent of the Framework Convention on Climate Change (developed at the 1992 UN Conference on Environment and Development) and the 1992 U.S. Energy Policy Act interest has grown in forest sector $\mathrm{C}$ offset projects (Dixon et al. 1993c). The U.S. private sector (e.g. PacifiCorp, New England Electric System, Applied Energy Services) has initiated forest establishment and management programs to conserve and sequester $\mathrm{C}$ (i.e. forest sector $\mathrm{C}$ offsets). Other producers of $\mathrm{CO}_{2}$ are participating in urban energy conservation programs such as the Global ReLeaf and Cool Communities programs (Sampson et al. 1992).

Our current understanding of the global C cycle remains incomplete but the terrestrial biosphere plays a significant role in $\mathrm{C}$ cycling processes (Sundquist 1993). Forest and agroecosystems are major $C$ pools and the annual $C$ flux through these systems is significantly greater than anthropogenic emissions to the atmosphere. The potential to manage terrestrial systems to conserve and sequester $\mathrm{C}$ appears promising, but further research is needed to understand the response and feedbacks of the terrestrial biosphere to projected climate change.

Acknowledgements. We thank 3 anonymous referees for their constructive comments. Lu Rose assisted with manuscript preparation. The information in this document has been partially funded by the U.S. Environmental Protection Agency. It has been subject to the Agency's peer and administrative review, and has been approved for publication as an EPA document. Mention of trade names or commercial products does not constitute endorsement or recommendation for use.

\section{LITERATURE CITED}

Akbari, H., Huang, J., Martien, P., Rosenfeld, A., Tasha, H. (1988). The impact of summer heat islands on cooling energy consumption and $\mathrm{CO}_{2}$ emissions. LBL-25179, Lawrence Berkeley Laboratory, University of California, Berkeley

Brown, S., Lugo, A. E., Iverson, L. R. (1992). Processes and lands for sequestering carbon in the tropical forest landscape. Wat. Air Soil Pollut. 64: 139-155

Cooper, C. F. (1983). Carbon storage in managed forest. Can. J. For. Res. 13: 155-160

Cramer, W. P., Solomon, A. M. (1993). Climatic classification and future global redistribution of agricultural land. Clim. Res. 3: 97-110

Cropper, W. P., Gholz, H. L. (1993). Constructing a seasonal carbon balance for a forest ecosystem. Clim. Res. 3: 7-12

Detwiler, R. P., Hall, C. A. S. (1988). Tropical forests and the global carbon cycle. Science 239: 42-47

DeWalle, D. R. (1978). Manipulating urban vegetation for residential energy conservation. In: Proceedings of the First National Urban Forestry Conference. USDA, Forest Service, Washington, DC, p. 267-283

Dixon, R. K., Andrasko, K. J., Sussman, F. G., Lavinson, M. A., Trexler, M. C., Vinson, T S. (1993a). Forest sector carbon 
offset projects: near-term opportunities to mitigate greenhouse gas emissions. Wat. Air Soil Pollut. (in press)

Dixon, R. K., Turner, D. P. (1991). The global climate cycle and climate change: responses and feedbacks from belowground systems. Environ. Pollut. 72: 245-262

Dixon, R. K., Winjum, J. K., Andrasko, K. J., Lee, J. J., Schroeder, P. E. (1993b). Integrated systems: assessment of promising agroforest and alternative land-use practices to enhance carbon conservation and sequestration. Clim. Change (in press)

Dixon, R. K., Winjum, J. K., Schroeder, P. E. (1993c). Conservation and sequestration of carbon: the potential of forest and agroforest management practices. Global environmental Change 3: 159-173

Glenn, E. P., Hodges, C. N., Leith, H., Pielke, R., Pitelka, L. (1992a). Growing halophytes to remove carbon from the atmosphere. Environment 34: 40-43

Glenn, E. P., Pitelka, L. F., Olsen, M. W. (1992b). The use of halophytes to sequester carbon. Wat. Air Soil Pollut. 64: 251-263

Graham, R. L., Wright, L. L., Turhollow, A. F. (1992). The potential for short-rotation woody crops to reduce $\mathrm{CO}_{2}$ emissions. Clim. Change 22: 223-238

Grainger, A. (1988). Estimating areas of degraded tropical lands requiring replenishment of forest cover. Int. Tree Crops J. 5: 31-61

Gregerson, H., Draper, S., Elz, D. (1989). People and trees: the role of social forestry in sustainable development. EDI Seminar Series, World Bank, Washington, DC

Houghton, J. T., Jenkins, G. J., Ephraums, J. J. (eds.) (1990). Climate change - the IPCC Scientific Assessment. Intergovernmental Panel on Climate Change, Cambridge University Press, Cambridge

Iverson, L. R., Brown, S., Grainger, A., Prasad, A., Liu, D. (1993). Carbon sequestration in tropical Asia: an assessment of technically suitable forest lands using geographic information systems analysis. Clim. Res 3: 23-38

Johnson, D. W. (1992). Effects of forest management on soil carbon storage. Wat. Air Soil Pollut. 64: 83-120

Kauppi, P. E., Mielikainen, K., Kuusela, K. (1992). Biomass and carbon budget of European forest, 1971 to 1990. Science 256: 70-74

King, G. A. (1993). Conceptual approaches for incorporating climatic change into the development of forest management options for sequestering carbon. Clim. Res. 3: 61-78

Kolchugina, T P., Vinson, T S. (1993). Carbon balance of the continuous permafrost zone of Russia. Clim. Res. 3: 13-21

Krankina, O. N., Dixon, R. K. (1993). Forest management options to conserve and sequester terrestrial carbon in the Russian Federation. World Resources Rev. (in press)

Leemans, R., Solomon, A. M. (1993). Modeling the potential change in yield and distribution of the earth's crops under a warmed climate. Clim. Res. 3: 79-96

Lugo, A. E., Wisniewski, J. (1992). Natural sinks of $\mathrm{CO}_{2}$ : conclusions, key findings and research recommendations from the Palmas del Mar workshop. Wat. Air Soil Pollut. 64: $455-459$

Marland, G., Marland, S. (1992). Should we store carbon in trees? Wat. Air Soil Pollut. 64: 181-195

Mooney, H. A., Drake, B. G., Luxmoore, R. J., Oechel, W. C.,
Pitelka, L. F. (1991). How will terrestrial ecosystems interact with the changing $\mathrm{CO}_{2}$ concentration of the atmosphere and anticipated climate change? Bioscience 41: $96-104$

NAS (National Academy of Sciences) (1991). Policy implications of greenhouse warming. National Academy Press, Washington, DC

Norby, R. J., Gunderson, C. A., Wullschleger, S. D., O'Neill, E. G., McCracken, M. K. (1992). Productivity and compensatory responses of yellow-poplar trees in elevated $\mathrm{CO}_{2}$. Nature 357: 322-324

RTI (Research Triangle Institute) (1991). Biomass state-of-theart assessment. Report EPRI GS-7471s, Electric Power Research Institute, Palo Alto, CA

Sampson, R. N., Moll, G. A., Kielbaso, J. J (1992). Opportunities to increase urban forests and the potential impacts on carbon storage and conservation. In: Sampson, R. N., Hair, D. (eds.) Forests and global change, Vol. 1, Opportunities for increasing forest cover. American Forests, Washington, DC, p. 51-72

Sanchez, P. A., Bennites, J. R. (1987). Low-input cropping for acid soils of the humid tropics. Science 238: 1521-1527

Schlessinger, W. H. (1990). Evidence from chronosequence studies for a low carbon-storage potential of soils. Nature 348: $232 \div 234$

Schroeder, P. (1993). Agroforestry systems: integrated land use to store and conserve carbon. Clim. Res. 3: 53-60

Sedjo, R. A. (1992). Temperate forest ecosystems in the global carbon cycle. Ambio 21: 274-277

Strain, B. R., Thomas, R. B. (1992). Field measurements of $\mathrm{CO}_{2}$ enhancement and climate change in natural ecosystems. Wat. Air Soil Pollut. 64: 45-60

Sundquist, E. T. (1993). The global carbon dioxide budget. Science 259: $934-941$

Tans, P. P., Fung, I. F., Takahashi, T (1990). Observational constraints on the global atmospheric $\mathrm{CO}_{2}$ budget. Science 247: 1431-1438

Trexler, M. C., Haugen, C. (1993). Keeping it green: evaluating tropical forestry strategies to mitigate global warming. World Resources Institute, Washington, DC (in press)

Trexler, M., Meganck, R. (1993). Biotic carbon offset programs: sponsors of or impediment to economic development? Clim. Res. 3: 129-136

U.S. EPA (Environmental Protection Agency) (1992). Cooling our communities: a guidebook on tree planting and lightcolored surfacing. Report 22P-2001, U.S. EPA, Washington, $\mathrm{DC}$

Unruh, J. D., Houghton, R. A., Lefebvre, P. A. (1993). Carbon storage in agroforestry: an estimate for sub-Saharan Africa. Clim. Res. 3: 39-52

Wall, G. (ed.) (1992). Implications of climate change for Pacific Northwest forest management. University of Waterloo, Ontario

Winjum, J. K., Lewis, D. (1993). Forest management and the economics of carbon storage: the nonfinancial. Clim. Res. 3: $111-119$

Winjum, J. K., Dixon, R. K., Schroeder, P. E. (1992). Estimating the global potential of forest and agroforest management practices to sequester carbon. Wat. Air Soil Pollut. 64: $213-228$ 